\title{
Framing Transparency in the Obama Administration
}

\author{
Theresa Herrmann
}

\section{Introduction}

The very first episode of the British television series Yes Minister, entitled Open Government, cynically narrates the fate of a White Paper on Open Government, adopted by the new Minister of Administrative Affairs on his first day in office but ultimately discarded. Referring to this policy, the cabinet secretary invokes the 'law of inverse relevance': "The less you intend to do about something, the more you have to keep talking about it."

The point of departure is similar enough to begin this chapter on the framing of government transparency in the current US administration with this anecdote. Transparency has been a buzzword during the 2008 campaign and Obama's first term in office. President Obama's first executive act on his first day in office consisted of signing the Memorandum on Transparency and Open Government. However, the Obama administration's use of transparency - the term and the associated policies - has received surprisingly little academic interest, although it constitutes an opportunity to enhance understanding of transparency's role and value as a governmental reform strategy (cf. Coglianese, 2009, p. 530).

This chapter examines the framing of transparency as a governmental reform policy in the US-American context. It concentrates on the Obama administration's government transparency policy, the Open Government Initiative and related policies, rather than on targeted transparency policies imposed on corporations or other private organizations to reduce risks or improve performance (on the latter cf. Fung et al., 2007). It is attentive to the 'usages', the purposes and functions, of transparency rather than seeing transparency as a basic right and intrinsic value (on the latter cf. Stiglitz, 1999). This however neither implies that transparency can be used as a means to any end nor that there is no underlying political philosophy or public administration theory behind a government's notion(s) of transparency.

When analyzing public policies one can concentrate on (1) policy discourses (what governments say), (2) policy outputs (what governments do), or (3) policy outcomes (what 
governments achieve; Radulova, 2011, p. 50). This study concentrates on the first of these, by applying a policy frame analysis/ qualitative content analysis to the government's discourse on transparency. The dataset analyzed is composed of thirty-one official documents covering the time span from January 2006 to April 2012. The chapter addresses the purpose of Obama's government transparency policy: how has the administration framed transparency and what is transparency meant to do? It aims to contribute to a better understanding of transparency as a governmental strategy. Its novelty lies in the systematic identification and analysis of transparency frames in primary documents of the administration.

The chapter traces four frames in the administration's discourse on government transparency - trust in democratic government, improvement of policies, accountability, and the implementation of the Recovery Act - that partly mirror the purposes mentioned by the theoretical literature. It focuses on discursive frames, but is attentive to some degree to external circumstances - actual events or developments as well as counter-narratives - as frames do not come up in a vacuum and are not carved in stone. Particularly, the chapter finds that in a crisis context, the emphasis is - strategically, one could argue - on accountability of spending and gaining citizen support.

The chapter studies a topical issue. A literature search yields few contributions that consider governmental reform strategies based on transparency. Even though Obama has put transparency into the spot light, a systematic analysis of his administration's discourse on transparency has, to my knowledge, not taken place beyond some references to his statements. The study of primary documents is still necessary. The policy is of course very recent; and exceptions to the rule are Coglianese (2009) and Birchall (2011a). Like Coglianese, this chapter repeatedly draws attention to the strategic promotion of transparency policies. Both Coglianese and Birchall find that the logic for Obama's transparency policy is stronger in the short than in the long run. An interesting question is hence whether there has been a development in how transparency has been framed.

The chapter is structured in the following way: the next section presents the purposes of transparency policies identified in the literature and contextualizes transparency's presumed triumph under the Obama administration. The next section introduces the analytical framework, the methodology of the study, and the selection of primary sources. Subsequently, the transparency frames employed in the dataset are analyzed. Conclusions can be drawn by discussing the dynamics of transparency framing in the Obama administration. 


\section{Contextualizing Obama's Open Government Initiative}

Obama made government transparency an issue in his presidential election campaign and signed the Memorandum on Open Government and the Memorandum on the Freedom of Information Act on his first day in office. These documents commit his administration to "creating an unprecedented level of openness in Government" and base it on the three principles of transparency, (public) participation, and collaboration (White House, 2009a). The ensuing Open Government Directive (OMB, 2009) required departments and agencies to publish more quality information online, to create or improve interactive Open Government websites (including Recovery.gov, Regulations.gov, USAspending.gov, Foreignassistance.gov, and Healthreform.gov), and to institutionalize a culture of open government in their staff regulations. This had to be implemented within a few months.

A deeper analysis of the purpose or the stated aims of Obama's government transparency policy is still necessary. This chapter claims that two circumstances should be taken into account as incentives for Obama's open government initiative: the previous Bush administration's reputation for secrecy and the enduring financial-economic crisis. Both can be linked to a climate of distrust in government. At the same time, it is assumed that Obama's policy has both strategic and normative underpinnings and considerations. Before investigating these in the empirical part of the chapter, this section situates Obama's open government initiative in its temporal, strategic, and normative context and introduces the commonly identified usages of transparency.

\section{Transparency as a Tool for Better Governance}

For the purposes of this chapter, transparency is defined as "the condition in which knowledge of activities that are of public interest is revealed" (Sturges, 2007, p. 4). It is thus about exposing the conduct of the powerful - mainly the politically powerful in this case, but it could also be the economically or otherwise powerful - to the public. The nongovernmental anti-corruption organization Transparency International has expressed this by defining transparency as "a principle that allows those affected by administrative decisions, business transactions or charitable work to know not only the basic facts and figures but also the mechanisms and processes" (quoted in Sturges, 2007, p. 4). On a basic level, government transparency means open government and freedom of (access to) information - i.e., formal disclosure procedures in the public sector (pp. 6-7; cf. Hood, 2007a, pp. 14-15). In practice, this may amount to rather passive rights.

With what aim are information and conduct disclosed? This chapter does not merely treat transparency as a basic right, public good, or an intrinsic value. Transparency is normally not implemented for the sake of transparency itself but it is used to reach the 
normative goal of good governance. Transparency's most commonly declared functions can be sub-divided into 'affirmative' and 'preventive' ones (Coglianese, 2009, pp. 535-36). Affirmatively, transparency is supposed to improve governmental decision-making and policies by enabling well-informed public participation. In this way, the circle of those providing input into policy-making processes is widened which is taken to enhance quality. It allows governments to draw on the expertise or the local perspective of its citizens (including experts and interest groups). Preventively, transparency is supposed to make abuses, mismanagement, and mistakes committed by government officials less likely. According to Fung (in Holmes, 2009), "the discourse of governmental transparency is primarily about accountability"; in the conceptualization of Bessire (2005), transparency has the function of disciplining individuals (government officials, in this case) who are assumed to behave in an opportunistic way (pp. 427-28). Transparency's classic affirmative and preventive functions were already invoked at the time of the US founding fathers (Stiglitz, 1999, pp. 5-7).

Heald (2007a) argues for transparency as an instrumental value and conceptualizes it as a set of trade-offs or synergies with other objectives that can be rank-ordered according to an individual's background and ideology (pp. 59, 68). He identifies seven of such objectives: effectiveness; trust; accountability; autonomy and control; confidentiality, privacy, and anonymity; fairness; and legitimacy. One can recognize effectiveness, trust, fairness, and legitimacy in the affirmative camp while accountability and autonomy/ control entail preventive functions.

To summarize, important functions of transparency policies are to enhance effectiveness - in the sense of more responsive, more cost-effective, or more democratic policies - and citizen trust, and to establish accountability and control. Surveying the temporal context into which Obama's initiative is embedded sheds light on the appeal of making the government more transparent and hence responsive, efficient, and trustworthy.

\section{The Temporal and Strategic Context}

With trust being one of the objectives mentioned above, the presumed current 'crisis of trust' - or "culture of suspicion" (O'Neill, 2002, pp. 18-19, 44-45) - springs to mind. Opinion polls illustrate that the high levels of trust in US governments during the Eisenhower, Kennedy, and Johnson administrations - with over $70 \%$ of those polled trusting the government "just about always" or "most of the time" - have not been matched after these years (Pew Research Center, 2010). Most recently a staggering $80 \%$ of those polled expressed to trust the government "only some of the time" or even "never" (ibid.; cf. Gallup, 2011; CNN, 2011). 
Though there is no space to go into the reasons for this development, it can be assumed that the financial crisis has played a role in further diminishing trust that the government can handle the nation's problems effectively. Recession, high unemployment rates, and loss of house ownership have severely challenged dearly held conceptions of the American dream. Distrust can be a consequence of a lack of information about a government's activities, while transparency can be expected to be transformed into trust. Hence, in a crisis context, enhanced transparency could well be imagined as a way to bring the administration and its regulatory policies closer to the public again.

The reputation for secrecy of the preceding Bush administration has to be taken into account as well. Most denounced was Bush's posture over international and homeland security issues in the aftermath of the September 11, 2001 terrorist attacks. Secrecy prevailed as well in certain aspects of domestic policy-making. For instance, Vice-President Cheney chaired an energy policy task force that met secretly with industry representatives (Coglianese, 2009, p. 531). The administration also reversed a document declassification effort initiated by the Clinton administration (Birchall, 2011a, p. 136). A memorandum by Attorney General John D. Ashcroft informed agencies that "when you carefully consider FOIA [Freedom of Information Act] requests and decide to withhold records ... you can be assured that the Department of Justice will defend your decisions" (quoted in ibid., p. 137). Notorious is also the significantly increased invocation of the State Secret Privilege which prevents classified documents from being used as evidence in civil suits against the government for reasons of state security (p.136).

By contrast, Obama had already been involved in transparency policies and legislation on lobbying, both as a state senator in Illinois (1997-2004) and as a US senator (200508). During his presidential campaign he was able to credibly draw on this involvement. Calling for new transparency practices was hence also a way to distinguish the candidate Obama from the incumbent President Bush, which moreover fit well into Obama's overall campaign theme of 'change' and the self-confidence instilling "Yes, We Can" spirit. Coglianese (2009) explicitly refers to it as "a matter of political strategy" (p. 539). In the short term, there was a strong logic in favor of transparency policies since they are universally favored and distinguish the new administration from its predecessor's generally criticized or unpopular practices. Moreover, well-organized (business as well as public interest) groups benefit from enhanced transparency, while the potential losers are dispersed and unorganized. Finally, little additional budgetary resources are required (ibid.). 


\section{The Normative Context}

This is not to say that the Obama administration's recourse to transparency was merely based on strategic presumptions and lacked a philosophy behind it. Birchall (2011b) distinguishes a mainstream notion of transparency marked by neo-liberalism as opposed to a more radical anti-capitalist, anti-establishment notion at the other end of the continuum (p. 62). She situates the Obama administration on the mainstream end of the continuum. Indeed, transparency can have promoters with firm ideological convictions.13

Bryer et al. (2010), who survey the current US government's public administration theory, comment that Obama has shown himself pragmatist rather than ideological and, having recognized that markets do not solve all problems, aspires changes in public policy and administration. Yet, he frequently falls back on preconceived ideas and methods (pp. 118-19). The question remains whether the notion of transparency rests on commonsensical understandings of transparency as a normative and utilitarian good or whether a specific meaning and purpose is defined by the US government.

It could be argued that "transparency for Obama is more than simply an external goal to be achieved by policy" (Birchall, 2011a, p. 138). Not only has Obama been involved in transparency policies prior to his 2008 campaign, which gave him credibility. During his political career he has also carefully constructed an image of personal transparency and accessibility (ibid.). His uses of the internet, including social networks and videosharing sites, but also town-hall meetings exemplify this. In 1995, prior to his presidential ambitions, he moreover published a personal memoir, Dreams from My Father. While it is questionable whether what was created is only an 'illusion' or a rhetoric rather than a meaningful engagement of citizens in the political process (Bryer et al., 2010, p. 119), there has nevertheless been a new qualitative dimension to accessibility and transparency of a high-ranking political figure that is exemplified by the use of the internet.

Building on this background, the chapter's empirical part will analyze the Obama administration's framing of transparency including strategic and normative elements. Prior to the document analysis, the following section discusses the analytical framework and the composition of the dataset.

13 For instance, the liberal-progressive business magnate George Soros promotes transparency in Central and Eastern Europe through his Open Society Foundations. Soros has also massively donated to anti-conservative, anti-Republican, anti-Bush causes - not necessarily in a very transparent manner. 


\section{Analytical Framework: Framing and Policy Frame Analysis}

This chapter uses a qualitative, interpretivist analysis of documents produced by the administration to find out the intended functions of the Obama administration's transparency policy. The (constructivist) premise of this chapter is that public problems can be constructed in different ways. Interpretations and solutions or actions suggested as legitimate usually rest on normative assumptions (Radulova, 2009, p. 3); meaning and appropriateness can be more important than cost-benefit analyses (Yanow, 2000, p. v).

While framing analysis has been widely used in the social sciences and humanities mainly for analyzing media reporting and political speech - it has never developed into a rigorous method: "nowhere there is a general statement of framing theory that shows exactly how frames become embedded within and make themselves manifest in a text, or how framing influences thinking" (Entman, 1993, p. 51). Yet, there is agreement on the essential elements of framing being selection of aspects to highlight and emphasis of their salience. Entman (1993) provides a comprehensive definition that guides this chapter:

"To frame is to select some aspects of a perceived reality and make them more salient in a communicating text, in such a way as to promote a particular problem definition, causal interpretation, moral evaluation, and/or treatment recommendation for the item described. Typically frames diagnose, evaluate, and prescribe" (p. 52).

This could occur unconsciously; in this analysis it will however be seen as a purposive activity of the administration - or more generally of politicians, the media, experts, and others who have the power to propagate meaning.

Frames are an example of selective social representation that highlights certain valued aspects and excludes other more contradictory ones (Yanow, 2000, p. 11). A frame is accordingly an interpretive framework (ibid.), an organizing device (Gamson \& Modigliani, 1989, p. 3): frames are employed as a mental shortcut, to make sense of complex issues or situations and to define their salience. An effective frame fits into a larger system of meaning; it resonates with other commonly invoked frames, the cultures and beliefs of the population at which it is aimed (Entman, 1993, pp. 52-53; Gamson \& Modigliani, 1989 , p. 5). To be viable, a frame needs to be able to react to alternative interpretations and to incorporate seemingly contradictory events into its own narrative (ibid.). In the case studied here, one can think of how the administration reacts to the alternative, challenging framing of transparency by WikiLeaks.

Framing involves the use of language, often metaphorical language (Yanow, 2000, p. 12). Frames are present in a text in the form of keywords, stock phrases, images, stereotypes, information, sentences, repetitions, silences, and associations with culturally familiar 
symbols (Entman, 1993, pp. 52, 53). But how to recognize a frame in the analysis? Building on Entman (1993, p. 52) and Radulova (2011, pp. 42-43), four functions or dimensions of policy frames can be discerned:

- Frames identify and define problems (constitutive dimension).

- Frames diagnose causes or suggest cause-effect explanations of the problem (cognitive dimension).

- Frames propose certain (non-)actions or policies that could remedy or solve these problems (policy dimension).

- The identification of problems, their moral judgment, and acceptable solutions are based on certain (political) values, norms or principles (normative dimension).

When analyzing the texts, one has to be aware that one sentence may perform more than one of these framing functions ${ }^{14}$ and many sentences do not perform any of them. The four dimensions are not necessarily all present in a text; especially the underlying normative principles may not be made explicit in a policy document.

Yanow (2000) distinguishes two kinds of framing analyses, "a comparative analysis across communities of meaning, at a (relatively) fixed point in time, of the various ways in which a policy issue has been 'framed', that is, interpreted and understood" as opposed to "a more dynamic analysis of changes in issue 'framing' over time, possibly within a single community of meaning" (p. 13). This study belongs into the latter category. Since the study focuses on one administration - even though this is not to suggest that it is a monolithic actor - over the rather short period of six years, major changes in the discourse should not be expected. Nor will the frames employed be mutually exclusive or competing as they could be if the discourse of several actors, each with their own agendas, was studied. While the aim is to assign each document to one frame, some might contain elements of two or more frames. However, it is conceivable that nuances between the White House and the Department of State, between the candidacy and the presidency, or at different points in time might be found.

In the case of Obama's government transparency policies, transparency usually seems to be (part of) a policy solution. However, is a unitary account given of the normative, constitutive, and cognitive dimensions or can we observe an evolution of the frames employed? Before the results of the empirical analysis are presented, the sub-section below explains the selection of sources and the methods applied to them in more detail.

14 For instance, the sentence "The recent scandals have shaken the very foundation of the American people's faith in a government that will look out for their interests and uphold their values." (Obama, 2006a) identifies a problem and a cause, and, when seen in context, involves a moral judgment. 


\section{Dataset and Selection of Sources}

The dataset consists of thirty-one documents covering the years 2006 to (April) 2012, from Obama's candidacy throughout his first presidential term (cf. reference section and overview table in the appendix). ${ }^{5}$ They include campaigning literature, speeches, memos and directives, press releases, remarks, and transcripts of addresses at meetings within the administration.

The majority of sources stems from the official websites of the White House and the Department of State, which ensures their reliability, leaving aside any suspicions of censorship. Some relevant campaign and policy documents were identified during the literature search and then directly searched for on the internet. ${ }^{16}$ Otherwise, the search started with a keyword search on the 'remarks and statements' and the 'press releases' sections of the respective homepages. Keywords used for the search were "transparency", "transparent", and "open + government." The results were cross-checked by skimming through the documents to establish their context and relevance.

A choice has been made to concentrate on speeches, remarks, and transcripts of meetings rather than policy and implementation documents or general press releases. The former ones directly address specific audiences (while also being made available to the public as a whole) and explain government transparency as conceived of by the administration, which allows checking for differences in emphasis. For reasons of manageability of the qualitative analysis, the dataset had to be limited to thirtyone documents. Most of them transcribe Obama or Clinton, the most visible and vocal components of the administration. While the dataset cannot be claimed to be complete, it is held to be representative of the administration's discourse on government transparency as the various documents are spread evenly across the years and relate to a number of contexts in which the issue was raised.

15 Obama publicly declared his intention to run for president on February 10,2007 . Three speeches about transparency in lobbying dating from 2006 are included in the analysis since they feed into the campaign and since the decision to run for president was surely not taken spontaneously.

16 Official versions of pre-presidential speeches may be difficult to find. The campaign website Barackobama.com does not have an archive section of the 2008 campaign. The transition website Change. gov now links to the White House page. Though pre-presidency speeches found on blogs or Youtube were cross-checked, their reliability has to be hedged. In any case, the study is more concerned with the presidency than the candidacy. 
A qualitative content analysis informed by the theory of framing presented above was applied to the documents. The aim was to deconstruct the frames into their four dimensions and to reveal associations made between certain themes or keywords. The frames were identified on the basis of the literature search and the contextualization provided above as well as through text analysis itself. In the following empirical section each frame and its elements will be introduced and traced in the Obama administration's discourse on its government transparency policy.

\section{Framing Transparency as a Policy Solution}

Three documents can be said to be at the basis of the Obama administration's government transparency policy: the Presidential Memorandum on Transparency and Open Government (White House, 2009a), the ensuing Open Government Directive (OMB, 2009), and President Obama's remarks on the former to his senior staff and cabinet secretaries (White House, 2009b). They present the administration's government transparency reform and hint at its three-fold purpose, which is in line with the commonly invoked purposes mentioned above:

- To restore and maintain trust or faith in government;

- To hold government officials accountable;

- To improve the government's policies, responsiveness, and efficiency.

These stated purposes lay the basis for three frames, although the three documents do not provide the frames' complete narratives. A fourth frame is identified in relation the implementation of the American Recovery and Reinvestment Act of 2009 (henceforth: Recovery Act).

With the help of the primary materials, the following sub-sections analyze each frame in turn and identify the respective problems, causes, moral judgments, and remedies proposed as well as the times when a frame was more prominent than others. Tables summarizing the frames' dimensions and occurrences in the documents studied can be found in the appendix.

\section{Frame 1: Trust in Democratic Government}

The first frame predominates during the 2008 election campaign and then again in the runup to the November 2010 House of Representatives elections, in relation to the influence of 
'disguised' special interest groups on the elections and the debate over the DISCLOSE Act."7

The problem identified by this frame is a "deficit of trust" (White House, 2010b) across all political camps (Obama, 2007): citizens have lost trust that the parties and the government efficiently advance the people's interests and values; instead one can observe "what appears to be a systematic takeover of our democracy by high-priced lobbyists" (Obama, 2006a; cf. White House, 2010e). A sense of cynicism and discredit about the public service has developed. As a consequence, democracy is damaged or weakened, even threatened (White House, 2010d, 2010f). The temporal contextualization provided above has problematized the same trend of a lack of trust over the last decades.

Prior to Obama's presidency, the causes identified center on a "crisis of corruption" (Obama, 2006a, 2006b) and "a town called Washington that is more corrupt and more wasteful than it was before" (Obama, 2007). An explicit link is made with the incumbent Bush administration. Obama mentions recent corruption and bribery investigations involving public officials (Obama, 2006b, 2006c). By claiming that scandals have been the rule under Republican leadership, the problem is depicted in drastic terms (Obama, 2006b).

Hence, a first cause of this state of affairs is that the resources and the influence of lobbyists have become disproportionate during the Bush years, with the consequence that "lobbyists write national policies" (Obama for America, 2008) leading to "morally offensive conduct" and "morally offensive legislation" (Obama, 2006a). The situation has also led to wasteful spending on the part of the policy-makers (Obama for America, 2008). Hence, Americans are "tired of trusting us with their tax dollars when they see them spent on frivolous pet projects and corporate giveaways" (Obama, 2006c).

A second and related cause is the culture of secrecy and "backroom deals" in and around the government (Obama, 2006b). Obscurity obviously prevents accountability: "When the people running Washington are accountable only to the special interests that fund their campaigns, of course they'll spend your tax dollars with reckless abandon" (Obama, 2006a).

Another source of distrust identified by this frame is located in the dire economic circumstances. In a Democratic party-internal discussion, Senator Bayh describes "a sense of unfairness" preoccupying American citizens who are constantly making sacrifices which they do not see mirrored in Washington (White House, 2010b). Concerning a consequent loss of trust of his own party or government, Obama says, referring to the inherited deficit of \$1.3 trillion, "part of it was just bad timing.... you didn't construct the bomb, but you're

17 Democracy Is Strengthened by Casting Light On Spending in Elections Act, which would require corporate political advertisers to reveal who is funding their advertisements. 
holding it. ... It just looks like Washington business as usual. And all that suspicion gets amplified" (White House, 2010b). He calls for more transparency when he suggests the following remedy: "I think the way that we regain trust is to pursue good policies but not be afraid also to explain these policies, and to be honest with the American people that we're not going to dig ourselves out of this hole overnight" (White House, 2010b). In this respect, it is important to openly address misperceptions that exist in the public and create this sense of unfairness, suspicion, or mistrust. This includes transparency about the make-up of the budget (ibid.).

As can be seen, especially during the campaign for the 2008 elections, Obama and his team have put an emphasis on denouncing the practices of the current administration and on distinguishing themselves from it by calling for reform to "change Washington" (Obama for America, 2008). The problem is portrayed in a very pronounced and acute way by calling it a "crisis of corruption" and a threat to democracy, whereas change under Obama's administration is portrayed as a remedy and reversal. Transparency is frequently emphasized as an important part of his solution. At times, Obama uses rhetoric figures when speaking about transparency - such as repetitions and alliterations - that give his words added effect and make his agenda memorable (cf. Obama, 2006b).

The distinction between the Republicans and the Democrats is also made in the runup to the 2010 House of Representatives elections. For instance, in his remarks prior to the vote on the DISCLOSE Act in the Senate, Obama portrays himself as the voice of the people in difficult times whereas the Republicans are obstructing legislation about reducing corporate or even foreign influence over US elections (White House, 2010d, 2010e). When addressing fellow-Democrats, Obama explicitly denounces a smear campaign against his party and public servants led by interest groups close to the Republicans (White House, 2010e; cf. White House, 2012f).

Hence, this frame mainly comes up in a context of approaching elections and has a strategic aspect of distinguishing Obama and the Democrats from their political rivals. Yet, underlying values and moral judgments are provided in this frame as well, namely democratic concerns since the government that the citizens would have faith in is "a government of, by, and for the American people" (Obama, 2006a). There are several references to valued historical personalities who fought corruption and special interest, such as James Madison and Theodore Roosevelt (in Obama, 2006b and 2006c; White House, 2010d). These references can be expected to resonate with widespread democracy frames. Moreover, the administration puts itself into this particular democratic tradition, while the conduct and legislation of the preceding administration is judged as morally offensive. Lobbyists and special interest are continuously represented in an unfavorable light; their role in democracy is not acknowledged. At the same time, the strong rhetoric 
and vision - particularly during the 2008 elections campaign - remain general and it is not made explicit how they will be put into practice and how exactly transparency will improve trust in government. It seems to be assumed that disclosure of lobby group activities by itself will discipline special interests, law-makers, and administrators and instill public trust. No concrete ways are mentioned in this frame in which the public could denounce or correct misconduct and existing practices.

\section{Frame 2: Improvement of Policies (Affirmative Aspect)}

There are two contexts in which this frame is invoked, one concerned with domestic and one with foreign affairs. In both cases there is a close link made between transparency and technology and innovation, and there is the discourse of bringing the United States into the twenty-first century. Government transparency can namely also be seen as an adaptation to changes in the habitat (Heald, 2007b, pp. 37-40). A functional explanation for increased transparency is that it "is simply a necessary kind of adaptation to prevailing technological and social conditions for governments" (Hood, 2007b, p. 216). For instance, technology reduces costs of disclosure and enables citizens to access government information in the first place. However, it also opens up new possibilities for exertion of influence through information, as the foreign policy dimension of this frame will illustrate.

Such new ways are certainly welcome, given that this frame posits the underlying problem that the United States are falling behind in economic efficiency, competitiveness, and appeal and "none of this is acceptable - particularly at a time when we're experiencing such economic difficulty and so many people are struggling" (White House, 2010a). It also fits uncomfortably with the normative assumptions of the traditional superpower that should be expected to play a role model. This echoes the sense of mission that the USA has traditionally felt, including a concern to spread liberal-democratic values.

A cause given for the situation is that technology and innovation are not employed sufficiently and appropriately to solve the nation's problems: "outdated technologies and information systems ... undermine our efficiency and threaten our security, and fail to serve their interests" (White House, 2010a). There is a "need to synchronize our technological progress with our principles" (Clinton, 2010).

Domestically, it is about making the government and public administration more responsive, efficient, and accessible through technology and transparency. The discourse speaks of modernizing government. Citizens should be able to complete more bureaucratic processes - such as applications for social security, citizenship, business or student loans - online, which requires making them more transparent. Transparency and technology should be linked "to make a real difference in people's lives" (White House, 2010a). This customer and service orientation, coupled with reduced spending, hints at an underlying 
belief in the New Public Management paradigm. Accordingly, the administration has reached out to business representatives to learn from their experiences (ibid.).

Ever since the 2008 campaign, there is also the idea to substantially improve policies by tapping citizen expertise. According to this frame, enhanced transparency enabled through technology will increase informed and meaningful citizen participation and hence problem-solving (Obama for America, 2007, pp. 1, 5). The aim is "a transparent and connected democracy", with the underlying normative assumption that "democracy is strongest when its citizens can engage in the full and free exchange of information and ideas, including freely expressing themselves and learning from the information offered by others" (p. 2).

Yet, the use of the notion of transparency is not limited to domestic policies. The administration, particularly the Department of State under Hillary Clinton, has made transparency and internet freedom issues in its relations with other states. Here, interestingly, the state actively promotes transparency towards other states, rather than responding to some citizen demand for enhanced transparency as it might be doing domestically. This is due to both strategic and normative aspects, namely business interests and liberal-democratic values. A lack of transparency in international relations is identified as problematic because it deteriorates political and economic relations with other nations.

A first point on the administration's agenda is internet freedom around the world, which Hillary Clinton is the main proponent of. Her belief is that a combination of technology and freedom of information (including online organizing tools) can magnify the power and potential of all citizens, even vis-à-vis authoritarian governments. Technology and transparency are hence worth spreading as they advance democracy and human rights (Clinton, 2010). Allusions to democracy abound, though in the wake of WikiLeaks' release of diplomatic cables, Clinton insists more on the need to balance transparency and confidentiality in the interest of national security (Clinton, 2011). However, she plays the impact of WikiLeaks down and effectively appropriates the term 'transparency' for her administration, while she refers to WikiLeaks as a criminal act and does not comment on the authenticity of the contents of the released documents. She claims that the incident does not challenge the administration's commitment to transparency and internet freedom since "governments also have a duty to be transparent. We govern with the consent of the people, and that consent must be informed to be meaningful" (Clinton, 2011).

A second point on the agenda is the role of openness and transparency in relations between states. During his visit to China in November 2009, Obama stressed that "the success of that engagement [between China and the USA] depends upon understanding - on sustaining open dialogue, and learning about one another and from one another.... 
The more open we are, the more we can communicate. And it also helps to draw the world together" (White House, 2009j). He insists on some principles that his administration holds to be universal, including access to information and political participation. Increased openness between the two countries and enhanced internet freedom promise to enhance not only political relations, but economic goals seem to play a role as well - during his visit, Obama also defended Google in China (ibid.).

Obama has sought to institutionalize the commitment to transparency and open government internationally by initiating the Open Government Partnership at the United Nations General Assembly in September 2010. Established in September 2011, this multilateral initiative encompasses states - eight founding members have been joined by forty-seven other states until now - and civil society organizations. Its underlying idea is a commitment to "open economies, open societies, and open governments as the strongest foundation for human progress" (White House, 2011a). Here as well, there is an idea to empower citizens and to solicit their good ideas, and for this transparency is necessary (White House, 2011b). The national action plans adopted within the framework of the Open Government Partnership have committed the USA further down its road towards increased government transparency. In them, the link between transparency and technological progress is mentioned explicitly once again (Clinton, 2012b).

This link is indeed made use of in both domestic (cf. above) and international contexts. In the framework of its concept of Twenty-First Century Statecraft - defined as "the complementing of traditional foreign policy tools with newly innovated and adapted instruments of statecraft that fully leverage the networks, technologies, and demographics of our interconnected world"18 - the Department of State has made extensive use of the internet to inform about US policies, to connect with citizens as well as people everywhere, and to make development spending transparent (through the website Foreignassistance. gov; cf. Clinton, 2012b). Spreading information and images over the internet is a form of soft power, and popular culture can have an enormous impact on the minds of people all across the world.

Indeed, a sense of mission to promote liberal-democratic values is present in the discourse, especially on the Open Government Partnership. Open government is called "the essence of democracy" and Obama explicitly refers to integrating newly emerging democracies into global cooperation to tackle global problems together (White House, 2011b). These democracies can be strengthened by showing them "how innovations in

18 Retrieved June 02, 2012 from http://www.state.gov/statecraft/overview/index.htm. 
open government can help make countries more prosperous and more just" (ibid.). Indeed, in the words of Hillary Clinton,

"in the $27^{\text {st }}$ century, the United States is convinced that one of the most significant divisions among nations will not be north/south, east/west, religious, or any other category so much as whether they are open or closed societies. We believe that countries with open government, open economies, and open societies will increasingly flourish. They will become more prosperous, healthier, more secure, and more peaceful"

(Clinton, 2012b).

Both Obama and Clinton refer to the universality of the principle of openness and also to the positive consequences for business and competitiveness (Clinton, 2010; White House, 2009j). Openness enhances creativity, entrepreneurship, and innovation and hence productivity and competitiveness. Moreover, it inspires investors' confidence. There are also strategic considerations present in the administration's discourse on transparency in the foreign affairs realm. A problem is that US companies are disadvantaged if they face stricter transparency and anti-corruption requirements than their foreign, for instance Chinese, counterparts. The US hence strives for high standards when it comes to anticorruption and pro-transparency policies (Clinton, 2012a). Transparency, openness, and internet freedom are thus put forward to advance both US values and business interests; the internet is a tool in this respect. Clinton (2010) states that "by advancing this agenda we align our principles, our economic goals, and our strategic priorities."

In sum, within this frame, the Obama administration's open government initiative is extended - on the one hand from governments to economies and societies, on the other hand internationally. According to this discourse, promoting openness and transparency world-wide is a way of forging partnerships with other nations, a way of influence, and a way to enhance competitiveness and international appeal. Strategic considerations and liberal-democratic ideological underpinnings manifest themselves in the discourse on this frame.

\section{Frame 3: Accountability (Preventive Aspect)}

This frame first appears in the Memorandum on the Freedom of Information Act signed by President Obama on his first day in office. The only purpose given for freedom of information legislation in this memorandum is accountability; the correlations are assumed to be straightforward: "A democracy requires accountability, and accountability requires transparency" (White House, 2009c). The frame is invoked in relation to the budget, specifically earmarks, and the financial reform - i.e., tax dollars. 
The frame identifies political and economic problems: on the one hand, a lack of accountability is attested and it is implied that existing freedom of information legislation has not been implemented in an affirmative manner (White House, 2009c). On the other hand, there a fears that the intransparent derivatives market could bring the economy down again if large companies suffer liquidity crises and require bail-outs (White House, 2010c).

In relation to budget processes and freedom of information legislation, part of the problem is taken to be caused, similar to the first frame, by existing practices of a predecessor administration that lacked responsibility, transparency, and accountability (White House, 2009e). Prior to reform of the budget process, in March 2009, the President holds that earmarks were inserted in an intransparent manner, often in the last minute, without a way to find out the logic behind them. The culture of secrecy in decision-making is again denounced since these secretive practices make the abuse of earmarks possible (ibid.). Another cause for the problem is a culture of blame avoidance, meaning that disclosure might be avoided in order not to uncover mistakes made by officials (White House, 2009c).

With respect to financial markets, a concrete cause for fears was the liquidity crises of the multinational insurance corporation American International Group, Inc. which required the Federal Reserve Bank and the Treasury to grant it credits twice, in 2008 and in 2009 (White House, 2010c). The President explicitly tells his Economic Recovery Advisory Board that "we can't afford another AIG" (ibid.). Fears of further liquidity crises of large companies and prolonged economic recession are caused by financial markets which, if intransparent, are not controllable and foster reckless behavior (White House, 2009h).

In both cases the suggested remedy is increased transparency and hence accountability. With regard to the budget, there is the earmark reform which eliminates anonymous earmarks and requires legislators to disclose and justify suggested earmarks in advance (White House, 2009e). In relation to financial reform and federal spending, the terms "transparency" and "accountability" frequently appear as a pair (cf. Obama in White House, 2009h and 2010c). References are made to the launch of the websites Recovery.gov and USAspending.gov (White House, 2010g). The underlying normative dimension seems to be concerned with economic efficiency and with providing collective welfare efficiently.

This frame mirrors the preventive function of transparency: to discipline opportunistic individuals - in this case, decision-makers receptive for lobbyists at the expense of the public good as well as government officials protecting their personal interests at the expense of the citizens they are supposed to serve (cf.White House, 2009c), and individuals effecting risky financial bets. There is certainly the idea that making actions transparent will influence behavior of legislators, companies, and investors. 
Overall, while the mobilization of this frame is clearly linked to the budget (earmark) reform and financial reform, this discourse nevertheless seems more fractured and the narrative less elaborate than in the other frames. This is possibly the case because the theme of accountability also resurfaces in other frames, notably the implementation of the Recovery Act frame. The two discourses put forward different problems and causeeffect relationships though as is elaborated upon below.

\section{Frame 4: Implementation of the Recovery Act}

This frame originates in February 2009, after the Recovery Act has been decided upon, and it appears over the next year. It is mainly promoted by Vice-President Biden, who is ultimately responsible for overseeing the Act's implementation, and mainly addressed at cabinet members, state governors or legislatures, and other officials or administrators.

The problem lies in the extraordinary situation that requires "the most sweeping recovery plan in our nation's history" (White House, 2009g).Vice-President Biden mentions the crisis context (White House, 2009f) and that "we've never decided to spend almost a trillion dollars to try to jump-start the economy" (White House, 2009i). The situation is thus unprecedented with regard to the amount of the countercyclical spending, the need for the stimulus, and the urgency of action. This makes it all the more important that the usual implementation problems - rather technical ones and in terms of citizen support - are overcome, which is where transparency comes in. It is a priority to ensure that the money is spent quickly and efficiently at all decision points (White House, 2009d, 2009f, 2009g).

Implementation problems arise due to the complexity of putting centrally-decided policies into practice at the local level. The Recovery Act is implemented at the state level, while the federal administration allocates money and oversees implementation. On various levels, many actors are involved at various decision points and share power over outcomes. All have their own agendas, preferences, procedures, and senses of urgency. At best implementation takes time and at worst the final product on the ground does not closely mirror Washington's original intent and whiteboard design anymore. This is the classical phenomenon of the "complexity of joint decision and action" (Pressman \& Wildavsky, 1984).

The implementation of the Recovery Act is also problematic due to the necessity and the difficulty to rally citizen support while citizens suffer under the crisis and the uncertainties it entails (White House, 2009b). According to Obama, transparency is needed to illustrate government discipline and honest communication can foster the citizens' comprehension: 
"If you do the right thing, and you explain it clearly and you do it openly, I'm confident that the American people - you can have an adult conversation and say, this is not going to be easy, this is not going to be painless, we're going to be struggling for a while, but our future is bright" (White House, 2010b.)

Similarly, Vice-President Biden reminds state governors to clearly communicate longterm investments and their pay-off prospects since "people will support us if it appears as though what we're doing makes sense, we're accountable, and we're totally transparent" (White House, 2009f). At various occasions, Obama and Biden show awareness of the public support dimension and the heightened importance of responsibility and efficiency in a crisis context (cf. White House, 2009f, 2009g).

The remedies suggested to both technical implementation problems and a lack of public support advocate unprecedented levels of transparency to enable oversight over state agents by both the federal principals and the public. The basic idea is to "follow the money," going "beyond normal procedures to a higher level of transparency" (Orszag'9 in White House, 2009d). Vice-President Biden emphasizes the administration's determination to be more intrusive and all-encompassing in its oversight than before, with the aim "to prevent fraud and waste, as opposed to just simply detecting it and doing investigations and audits" (ibid.)

Concrete measures are well developed in this frame. They include: increased communication between federal and state inspector-generals, additional reporting by the state administrations to the federal Office of Management and Business and to the Office of the Vice-President, the launch of the website Recovery.gov where citizens can trace the money allocated under the Recovery Act (White House, 2009d); Vice-President Biden's weekly meetings with cabinet members (White House, 2009f); disclosure of contacts with lobbyists and their positions in relation to Recovery Act projects (White House, 2009g); and the establishment of an overseeing board under an inspector-general in the Department of Interior (White House, 2009i).

It is noteworthy that this frame deals with two directions of transparency in vertical relationships, with different though linked purposes. On the one hand, there is what Heald (2007b) calls transparency upwards, meaning that "the hierarchical superior/principal can observe the conduct, behaviour, and/or 'results' of the hierarchical subordinate/agent" ( $p$. 27). In this case, the Office of the Vice-President uses transparency to hold actors in the federal states accountable. On the other hand, there is transparency downwards, i.e. "the

19 Peter R. Orszag, Director of the Office of Management and Budget in the Executive Office of the President from January 2009 to July 2010. 
'ruled' can observe the conduct, behaviour, and/or 'results' of their 'rulers"' (ibid.). In this case, citizens and the media gain insights into how their rulers implement Recovery Act projects and what the results are, thereby contributing to holding them accountable and ideally developing increased support and trust.

The administration's priority to make Recovery Act implementation as efficient and successful as possible is not surprising. Managing and mastering the economic crisis was and is one of the predominant domestic issues of Obama's presidency; hence, the administration could expect to be evaluated according to its success or failure with regard to this endeavor. Apparently ineffective crisis management could cost an incumbent government re-election. Thus, here as well it can be argued that the introduction of enhanced transparency seems to have some strategic aspects to it. Firstly, the federal government makes clear that increased transparency is meant to serve close oversight purposes and that it would pass on the blame for inefficiencies and failures of the recovery effort to state governors and executive agents (White House, 2009d and 2009f). Since most documents coded in this frame are transcripts of addresses by the Vice-President to state governors and legislatures, they appear less formal than speeches directly to the public and they are unequivocal. Secondly, the transparency and accountability discourse in relation to the Recovery Act is strongest in the earlier months of the Act's implementation. It seems that before favorable results are available, transparency of process and outcomes is treated as a proxy to gain citizen support for the policy. This is mirrored in the fact that in later speeches, when these results are available - notably during the 2012 presidential campaign - Obama stresses the number of jobs saved and the like, but does not mention transparency as an achievement per se.

\section{Discussion and Conclusion:}

\section{Dynamics of Transparency Framing in the}

\section{Obama Administration}

When tracing the Obama administration's framing of government transparency, as has been done in this chapter, one can recognize the affirmative and preventive functions of transparency brought up in the conceptual background section. Frames 2 and 3 exhibit them most explicitly, but the other two frames also contain those elements. By way of conclusion, this section summarizes and discusses the main findings of this study. 
Firstly, the analysis has shown that the trust frame was predominant prior to elections. References to less tangible concepts with positive connotations, such as trust, seem popular during election campaigns directed at masses of people. Campaign discourses employed the straightforward logic of increasing transparency to increase trust, while omitting the details of how to put it into practice. Elections are of course also an opportunity to radically distinguish the Democrats from the Republicans, for which the topic of transparency was well suited due to the Bush administration's reputation for secrecy.

Secondly, much of the administration's discourse and of transparency's purpose is about accountability. Tax money ultimately plays a role in all four frames and the theme of accountability is the most consistent red line throughout all the documents studied. Also, most of the websites launched in the name of transparency are tellingly about allowing citizens to 'track the money'. This tendency seems to have been enhanced by the crisis context; the strong-worded recourse to transparency when implementing the Recovery Act is a case in point. It is noticeable that the constant emphasis on transparency of process has given way to an emphasis on achievements. It seems that before results could be presented, transparency of the implementation process, with all its positive connotations and links to accountability, served as the administration's insurance and a way to gain public support. In both the first and the second finding, one can hence see a strategic dimension to the employment of 'transparency.' The idea that transparency might actually increase cynicism and undermine trust - namely if mistakes are exposed but the public does not see any changes - is not acknowledged (cf. Fung in Holmes, 2009).

Thirdly, prior to the WikiLeaks incident of November 2010 limitations or restrictions to transparency are hardly mentioned, only in the remarks to the senior staff (White House, 2009b). A memo ordering a review of the handling of classified information was only adopted in the immediate aftermath of the WikiLeaks revelations (OMB, 2010). In general, WikiLeaks is said not to challenge the US' commitment to transparency and its impact is played down; for instance, the president himself does not speak on the matter. ${ }^{20}$ It is noticeable that in relation to WikiLeaks, no reference to 'transparency' is made, only to 'disclosure.' An explanation would be that the administration has appropriated the term 'transparency' for itself and seems to have clear conceptions of transparency and its positive correlation with accountability, trust, and good governance. Transparency is not an object of debate; the administration does not engage in a deeper discussion over the framing of transparency in the wake of WikiLeaks. 'Disclosure' could be seen as a more technical, formal, and passive term and procedure which has moreover not been appropriated by the

20 For this paragraph cf. White House (2010h, 2010i, 2010j), Reuters (2010), OMB (2010), Clinton (2011). 
administration. WikiLeaks is definitely not seen in the light of transparency and the service of the good; it is criminalized and depicted as a threat for national security.

Fourthly, while 'transparency' has been invoked frequently, there is a decline over time. The discourse on transparency reforms was most omnipresent in the beginning of Obama's presidency and during the launch of the Recovery Act implementation. The accountability frame is distributed most evenly over time, but it is also the most diffuse frame. In the 2012 presidential campaign, 'transparency' is not listed as an 'issue' anymore on the campaign website Barackobama.com. In campaign speeches, which can be read in the 'speeches and remarks' section of the White House website, no specific reference is made to achievements related to transparency by itself. This, as well as the point made about transparency as an initial proxy for results in case of the Recovery Act, again illustrates that transparency is indeed not mobilized for the sake of it but as a tool to reach other goals and values. In addition, an incumbent's candidacy for a second presidential term is conducive to other strategies than challenging a rival incumbent president. It seems that transparency has lost some of its salience and appeal during the presidency. More research on the impact of external influences - such as other public policy challenges coming up, the WikiLeaks revelations, criticism on the implementation of transparency policies, etc. - should be conducted. It seems that Coglianese (2009) rightly posits that that incentive structure for transparency is different in the long run than in the short run.

Fifthly, the understanding of 'government transparency' seems to have broadened over time, stretching into economic and foreign affairs. Most recently, the concept of transparency has been mobilized by the Department of State through the US-initiated Open Government Partnership, the Twenty-First Century Statecraft initiative, and the issue of internet freedom. These are the contexts in which references to transparency still abound. Requiring more transparency from partner countries strategically opens up ways for soft influence as well as economic opportunities. Especially in this usage, normative underpinnings - a sense of mission rooted in liberal-democratic values - are discernible as well.

This chapter has sought to expose the frames contained in the Obama administration's discourse on its government transparency initiative. It has worked out the problems defined and their causes, the suggested remedies, and the underlying normative considerations or value judgments while being attentive to strategic usages. This systematic framework of policy frame analysis provides for a certain internal validity of the findings within the dataset. This is the innovative aspect of this chapter, through which it contributes to deciphering the usages of transparency envisaged by the administration. The findings cannot be generalized to other governments and their transparency policies, but a comparison within the same framework could be useful. The dataset on the Obama administration could also 
be extended to more types of documents and ideally interviews with officials.

Beyond the discourse, more research should be conducted on the substance and the actual implementation of the government transparency policies. Only in that way can their success or failure eventually be evaluated. This would shed light on the question whether open government and transparency, terms that have without a doubt been employed very frequently under the Obama administration, might in the end fall under the law on inverse relevance posited in Yes Minister.

\section{Appendix}

Table 1: Overview of Policy Frames Related to Government

Transparency in the Obama Administratio

\begin{tabular}{|c|c|c|c|c|}
\hline Demensions & $\begin{array}{l}\text { Underlying } \\
\text { values/ moral } \\
\text { judgments } \\
\text { (normative } \\
\text { dimension) }\end{array}$ & $\begin{array}{l}\text { Problem } \\
\text { (Connstitutive } \\
\text { dimension) }\end{array}$ & $\begin{array}{l}\text { Cause(s) } \\
\text { (cognitive } \\
\text { dimension) }\end{array}$ & $\begin{array}{l}\text { Remedy (Policy } \\
\text { dimension) }\end{array}$ \\
\hline $\begin{array}{l}\text { Trust in } \\
\text { government - } \\
\text { f1 }\end{array}$ & $\begin{array}{l}\text { Democratic } \\
\text { concerns: } \\
\text { government } \\
\text { of, by, and for } \\
\text { the people. } \\
\text { References } \\
\text { to Roosevelt, } \\
\text { Madison. }\end{array}$ & $\begin{array}{l}\text { Democracy is } \\
\text { threatened. } \\
\text { American } \\
\text { citizens have } \\
\text { lost trust in } \\
\text { government. } \\
\text { Special } \\
\text { interests are } \\
\text { taking over the } \\
\text { government. }\end{array}$ & $\begin{array}{l}\text { Corruption } \\
\text { and waste of } \\
\text { tax dollars } \\
\text { under the Bush } \\
\text { administration. } \\
\text { Lobbyists' } \\
\text { influence. } \\
\text { Culture of } \\
\text { secrecy. } \\
\text { Republicans } \\
\text { are not willing } \\
\text { to act. Public } \\
\text { misperceptions. }\end{array}$ & $\begin{array}{l}\text { Enhanced } \\
\text { transparency } \\
\text { makes oversight } \\
\text { possible and } \\
\text { restores citizens' } \\
\text { trust and truly } \\
\text { democratic } \\
\text { government. } \\
\text { Honest } \\
\text { communication } \\
\text { with citizens. }\end{array}$ \\
\hline
\end{tabular}




\begin{tabular}{|c|c|c|c|c|}
\hline $\begin{array}{l}\text { Improvement - } \\
f_{2}\end{array}$ & $\begin{array}{l}\text { Liberal- } \\
\text { democratic } \\
\text { concerns and } \\
\text { sense of mission } \\
\text { internationally; } \\
\text { USA as } \\
\text { role model. } \\
\text { New Public } \\
\text { Management. }\end{array}$ & $\begin{array}{l}\text { US are falling } \\
\text { behind in } \\
\text { competitiveness } \\
\text { and appeal } \\
\text { Economie } \\
\text { difficulties. }\end{array}$ & $\begin{array}{l}\text { Technology and } \\
\text { innovation are } \\
\text { not employed } \\
\text { sufficiently/ } \\
\text { appropriately. } \\
\text { This fails } \\
\text { to serve US } \\
\text { interests, } \\
\text { undermines } \\
\text { efficiency and } \\
\text { security. }\end{array}$ & $\begin{array}{l}\text { Adapt to } 215 t \\
\text { century. More } \\
\text { transparency } \\
\text { and internet } \\
\text { freedom will } \\
\text { improve public } \\
\text { participation } \\
\text { and policies, US } \\
\text { competitiveness, } \\
\text { international } \\
\text { relations and } \\
\text { appeal. }\end{array}$ \\
\hline $\begin{array}{l}\text { Accountability- } \\
f_{3}\end{array}$ & $\begin{array}{l}\text { Economic } \\
\text { efficiency; } \\
\text { efficient } \\
\text { provision of } \\
\text { welfare. }\end{array}$ & $\begin{array}{l}\text { Lack of } \\
\text { accountability. } \\
\text { Neglectfully } \\
\text { implemented } \\
\text { freedom of } \\
\text { information } \\
\text { legislation. Fear } \\
\text { of economic } \\
\text { downturn. }\end{array}$ & $\begin{array}{l}\text { Culture } \\
\text { of secrecy } \\
\text { and blame } \\
\text { avoidance. } \\
\text { Abuse of } \\
\text { earmarks. } \\
\text { Liquidity crisis } \\
\text { and bail-out of } \\
\text { AIG. Financial } \\
\text { markets are not } \\
\text { controllable. }\end{array}$ & $\begin{array}{l}\text { Increase } \\
\text { accountability by } \\
\text { introducing more } \\
\text { transparency into } \\
\text { budget process } \\
\text { and financial } \\
\text { markets. }\end{array}$ \\
\hline $\begin{array}{l}\text { Implementing } \\
\text { Recovery act- } \\
f_{4}\end{array}$ & $\begin{array}{l}\text { Social- } \\
\text { democratic } \\
\text { concerns. } \\
\text { Economic } \\
\text { efficiency. } \\
\text { Controlling } \\
\text { agents (state } \\
\text { governments). }\end{array}$ & $\begin{array}{l}\text { Unprecedented } \\
\text { recovery plan } \\
\text { during the } \\
\text { financial/ } \\
\text { economic crisis. }\end{array}$ & $\begin{array}{l}\text { Implementation } \\
\text { problems: } \\
\text { complex joint } \\
\text { action with } \\
\text { federal states, } \\
\text { difficulty and } \\
\text { need to rally } \\
\text { public support. }\end{array}$ & $\begin{array}{l}\text { Transparency } \\
\text { will lead to } \\
\text { accountability } \\
\text { and efficiency, } \\
\text { which will foster } \\
\text { public support, } \\
\text { even before } \\
\text { results are } \\
\text { available. }\end{array}$ \\
\hline
\end{tabular}


Table 2: Occurrence of the Policy Frames in the Studied Documents

\begin{tabular}{|c|c|c|c|c|c|c|}
\hline Year & Speaker & Document & F1 & $F_{2}$ & $\mathrm{~F}_{3}$ & $\mathrm{~F}_{4}$ \\
\hline \multirow[t]{3}{*}{2006} & Obama & $\begin{array}{l}\text { Honest Leadership and Open Government } \\
\text { Speech (Obama, 2006a) }\end{array}$ & $\mathrm{x}$ & & & \\
\hline & Obama & $\begin{array}{l}\text { Statement Floor Debate on Ethics (Obama, } \\
2006 \text { b) }\end{array}$ & $\mathrm{x}$ & & & \\
\hline & Obama & Lobbying Reform Summit (Obama, 2006c) & $\mathrm{x}$ & & & \\
\hline \multirow[t]{2}{*}{2007} & $\begin{array}{l}\text { Obama for } \\
\text { America }\end{array}$ & $\begin{array}{l}\text { Connecting and Empowering All Americans } \\
\text { Campaign Booklet (Obama for America, } \\
\text { 2007) }\end{array}$ & & $x$ & & \\
\hline & Obama & $\begin{array}{l}\text { lowa Jefferson-Jackson Dinner Speech } \\
\text { (Obama, 2007) }\end{array}$ & $x$ & & & \\
\hline 2008 & Obama/Biden & Blueprint for Change (Obama \& Biden, 2008) & $x$ & & & \\
\hline \multirow[t]{11}{*}{2009} & Obama & $\begin{array}{l}\text { Memo Open Government (White House, } \\
\text { 2009a) }\end{array}$ & $x$ & $x$ & $x$ & \\
\hline & Obama & $\begin{array}{l}\text { Remarks Welcoming Senior Staff (White } \\
\text { House, 2009b) }\end{array}$ & $\mathrm{x}$ & $x$ & $x$ & \\
\hline & Obama & Memo FOIA (White House, 2009c) & & & $x$ & \\
\hline & $\begin{array}{l}\text { Biden/ Orszag²1/ } \\
\text { Devaney }^{22}\end{array}$ & $\begin{array}{l}\text { Remarks at First Recovery Plan Meeting with } \\
\text { Cabinet (White House, 2009d) }\end{array}$ & & & & $x$ \\
\hline & Obama & $\begin{array}{l}\text { Remarks on Earmark Reform (White House, } \\
\text { 2009e) }\end{array}$ & & & $x$ & \\
\hline & Biden & $\begin{array}{l}\text { Remarks Recovery Act Implementation } \\
\text { Conference (White House, 2009f) }\end{array}$ & & & & $\mathrm{x}$ \\
\hline & Obama/Biden & $\begin{array}{l}\text { Remarks to Representatives of the National } \\
\text { Conference of State Legislatures (White } \\
\text { House, 2009g) }\end{array}$ & & & & $x$ \\
\hline & Obama & $\begin{array}{l}\text { Remarks on Financial Rescue and Reform } \\
\text { (White House, 200gh) }\end{array}$ & & & $x$ & \\
\hline & Biden & $\begin{array}{l}\text { Remarks at Economic Recovery } \\
\text { Implementation Meeting with Cabinet } \\
\text { Members (White House, 2009i) }\end{array}$ & & & & $x$ \\
\hline & Obama & $\begin{array}{l}\text { Remarks at Town Hall Meeting with Future } \\
\text { Chinese Leaders (White House, 2009j) }\end{array}$ & & $x$ & & \\
\hline & Orszag & Open Government Directive (OMB, 2009) & $\mathrm{x}$ & $\mathrm{x}$ & $\mathrm{x}$ & \\
\hline
\end{tabular}




\begin{tabular}{|c|c|c|c|c|c|c|}
\hline \multirow[t]{8}{*}{2010} & Obama & $\begin{array}{l}\text { Remarks at the Forum on Modernizing } \\
\text { Government (White House, 2010a) }\end{array}$ & & $x$ & & \\
\hline & Clinton & $\begin{array}{l}\text { Remarks on Internet Freedom (Clinton, } \\
\text { 2010) }\end{array}$ & & $x$ & & \\
\hline & $\begin{array}{l}\text { Obama/ } \\
\text { Senator Bayh }\end{array}$ & $\begin{array}{l}\text { Remarks at the Senate Democratic Policy } \\
\text { Committee Issues Conference (White } \\
\text { House, 2010b) }\end{array}$ & $x$ & & & $x$ \\
\hline & Obama & $\begin{array}{l}\text { Remarks at a Meeting with the President's } \\
\text { Economic Recovery Advisory Board (White } \\
\text { House, 2010c) }\end{array}$ & & & $x$ & \\
\hline & Obama & $\begin{array}{l}\text { Remarks on the DISCLOSE Act (White } \\
\text { House, 2010d) }\end{array}$ & $x$ & & & \\
\hline & Obama & $\begin{array}{l}\text { Remarks at DCCC/ DSCC General Reception } \\
\text { (White House, 2010e) }\end{array}$ & $x$ & & & \\
\hline & Obama & $\begin{array}{l}\text { Remarks at a Rally in Minneapolis, } \\
\text { Minnesota (White House, 2010f) }\end{array}$ & $x$ & & & \\
\hline & Obama & $\begin{array}{l}\text { Remarks on the Federal Employee Pay } \\
\text { Freeze (White House, 2010g) }\end{array}$ & & & $x$ & \\
\hline \multirow[t]{4}{*}{2011} & Clinton & $\begin{array}{l}\text { Internet Rights and Wrongs Speech } \\
\text { (Clinton, 2011) }\end{array}$ & & $x$ & & \\
\hline & $\begin{array}{l}\text { White House } \\
\text { Press Secretary }\end{array}$ & $\begin{array}{l}\text { Fact Sheet on Open Government } \\
\text { Partnership (White House, 2011a) }\end{array}$ & & $x$ & & \\
\hline & Obama & $\begin{array}{l}\text { Opening remarks on Open Government } \\
\text { Partnership (White House, 2011b) }\end{array}$ & & $x$ & & \\
\hline & Obama & $\begin{array}{l}\text { Closing Remarks on Open Government } \\
\text { Partnership (White House, 2011C) }\end{array}$ & & $x$ & & \\
\hline \multirow[t]{2}{*}{2012} & Clinton & $\begin{array}{l}\text { Remarks Transparency International Award } \\
\text { (Clinton, 2012a) }\end{array}$ & & $x$ & & \\
\hline & Clinton & $\begin{array}{l}\text { Remarks Open Government Partnership } \\
\text { (Clinton, 2012b) }\end{array}$ & & $x$ & & \\
\hline
\end{tabular}

21 Peter R. Orszag, Director of the Office of Management and Budget in the Executive Office of the President from January 2009 to July 2010.

22 Earl E. Devaney, Inspector General for the Department of the Interior since 1999; in February 2009, President Obama chose him to oversee the $\$ 787$ billion American Recovery and Reinvestment Act stimulus plan. 


\section{Bibliography}

Bessire, D. (2005). Transparency: a two-way mirror? International Journal of Social Economics, 32(5), pp. 424-38.

Birchall, C. (2011a). "There's been too much secrecy in this city": the false choice between secrecy and transparency in US politics. Cultural Politics, 7(1), pp. 133-56.

Birchall, C. (2011b). Transparency, interrupted: secrets of the left. Theory, Culture \& Society, 28(7-8), pp. 60-84.

Bryer, T.A. et al. (2010). Public administration theory in the Obama era. Administrative Theory \& Praxis, 32(1), pp. 118-22.

Coglianese, G. (2009). The transparency president? The Obama administration and open government. Governance: An International Journal of Policy, Administration, and Institutions, 22(4), pp. 529-44.

CNN (2011, September 28). CNN poll: trust in government at all-time low. Retrieved May 17, 2011 from http://politicalticker.blogs.cnn.com/2011/og/28/cnn-poll-trust-ingovernment-at-all-time-low/.

Entman, R.M. (1993). Framing: toward clarification of a fractured paradigm. Journal of Communication, 43(4), pp. 51-58.

Fung, A., M. Graham, \& D. Weil (2007). Full disclosure: the perils and promise of transparency. Cambridge: Cambridge University Press.

Gallup (2011). Trust in government. Retrieved May 17, 2011 from http://www.gallup. com/poll/5392/trust-government.aspx.

Gamson, W.A. \& A. Modigliani (1989). Media discourse and public opinion on nuclear power: a constructionist approach. American Journal of Sociology, 95(1), pp. 1-37.

Heald, D. (2007a). Transparency as an instrumental value. In C. Hood \& D. Heald (Eds.), Transparency: the key to better governance? (pp. 59-73). Proceedings of the British Academy, 135. Oxford: Oxford University Press.

Heald (2007b). Varieties of transparency. In C. Hood \& D. Heald (Eds.), Transparency: the key to better governance? (pp. 25-43). Proceedings of the British Academy, 135. Oxford: Oxford University Press.

Holmes, A. (2009, September 03). Defining transparency. Interview with A. Fung. NextGov: Technology and the Business of Government. Retrieved November 23, 2011 from http://www.nextgov.com/nextgov/ng_20090903_7217.php.

Hood, C. (2007a). Transparency in historical perspective. In C. Hood \& D. Heald (Eds.), Transparency: the key to better governance? (pp. 3-23). Proceedings of the British Academy, 135. Oxford: Oxford University Press. 
Hood, C. (2007b). Beyond exchanging first principles? Some closing comments. In C. Hood \& D. Heald (Eds.), Transparency: the key to better governance? (pp. 211-25). Proceedings of the British Academy, 135. Oxford: Oxford University Press.

Office of Management and Budget (OMB), Executive Office of the President (2010, November 28). Memorandum for the heads of executive departments and agencies. Subject: WikiLeaks - mishandling of classified information. Retrieved May 24, 2012 from http://www.whitehouse.gov/sites/default/files/omb/memoranda/2011/m11-06.pdf.

O'Neill, O. (2002). A question of trust. The BBC Reith Lectures. Cambridge: Cambridge University Press.

Pew Research Center for the People \& the Press (2010, April 18). Public trust in government: 1958-2010. Retrieved May 17, 2012 from http://www.people-press. org/2010/04/18/public-trust-in-government-1958-2010/.

Pressman, J.L. \& A. Wildavsky (1984). Chapter 5: The complexity of joint action. In Implementation - How great expectations in Washington are dashed in Oakland; or, why it's amazing that federal programs work at all. $3^{\text {rd }}$ edition. Berkeley: University of California Press.

Radulova, E. (2009). The construction of EU's childcare policy through the open method of coordination. In S. Kröger (Ed.), What we have learnt: advances, pitfalls and remaining questions in OMC research. European Integration Online Papers (EloP), Vol. 13, Special Issue 1, Art. 13. Retrieved May 10, 2012 from http://eiop.or.at/eiop/texte/2009-013a.htm.

Radulova, E. (2011). Europeanization through framing? An inquiry into the influence of the open method of coordination on childcare policy in the Netherlands. PhD thesis. Maastricht: Maastricht University.

Reuters Press Agency (2010, November 28). Text of State Department letter to Wikileaks. Retrieved March 05, 2012 from http://Www.reuters.com/article/2010/11/28/uswikileaks-usa-letter-idUSTRE6AR1E420101128.

Stiglitz, J.E. (1999, Jan. 27). On liberty, the right to know, and public discourse: the role of transparency in public life. Oxford: Oxford Amnesty lecture. Retrieved November 23, 2011 from http://siteresources.worldbank.org/NEWS/Resources/oxford-amnesty.pdf.

Sturges, P. (2007). What is this absence called transparency? International Review of Information Ethics, 7, pp. 1-8.

White House (2010h, July 27). Remarks by the president after bipartisan leadership meeting. Rose Garden. Retrieved May 06, 2012 from http://www.whitehouse.gov/thepress-office/remarks-president-after-bipartisan-leadership-meeting.

White House, Office of the Press Secretary (2010i, November 28). Statement by the Press Secretary. Retrieved May 24, 2012 from http://www.whitehouse.gov/the-pressoffice/2010/11/28/statement-press-secretary. 
White House, Office of the Press Secretary (2010j, November 29). Press briefing by Press Secretary Robert Gibbs. Retrieved May 24, 2012 from http://www.whitehouse.gov/ the-press-office/2010/11/29/press-briefing-press-secretary-robert-gibbs-11292010.

Yanow, D. (2000). Conducting interpretive policy analysis. Sage University Papers Series on Qualitative Research Methods, Vol. 47. Thousand Oaks, CA: Sage Publications.

\section{The Dataset:}

Clinton, H.R. (2010, January 21). Remarks on internet freedom. Speech at The Newseum, Washington, DC. Retrieved October 06, 2011 from http://www.state.gov/secretary/ $\mathrm{rm} / 2010 / 01 / 135519 . h t m$.

Clinton, H.R. (2011, February 15). Internet rights and wrongs: choices and challenges in a networked world. Speech at George Washington University, Washington, DC. Retrieved April 23, 2012 from http://www.state.gov/secretary/rm/2011/02/156619.htm.

Clinton, H.R. (2012a, March 22). Remarks at the Transparency International-USA's Annual Integrity Award dinner. The Mayflower Hotel, Washington, DC. Retrieved April 23, 2012 from $h t t p: / / w w w . s t a t e . g o v / s e c r e t a r y / r m / 2012 / 03 / 186703 . h t m$.

Clinton, H.R. (2012b, April 17). Remarks at the Open Government Partnership opening session. Brasilia, Brazil. Retrieved April 23, 2012 from http://www.state.gov/secretary/ $\mathrm{rm} / 2012 / 04 / 188008$.htm.

Obama, B.H. (2006a, January 18). Honest leadership and open government. Speech. Retrieved May 26, 2012 from http://obamaspeeches.com/o44-Remarks-Honest-Leadershipand-Open-Government-Obama-Podcast.htm.

Obama, B.H. (2006b, January 26). Lobbying reform summit speech. National Press Club, Washington, DC. Retrieved May 26, 2012 from http://obamaspeeches.com/o47-LobbyingReform-Summit-National-Press-Club-Obama-Speech.htm.

Obama, B.H. (2006c, March 07). Senator Obama's opening statement - floor debate on ethics reform. Retrieved May 26, 2012 from http://obamaspeeches.com/o55-Debate-onEthics-Reform-Obama-Speech.htm.

Obama, B.H. (2007, November 10). lowa Jefferson-Jackson Dinner speech. Des Moines, lowa. Retrieved May 26, 2012 from http://www.asksam.com/ebooks/releases. asp?file=Obama-Speeches.ask\&dn=lowa\%2OJefferson\%2dJackson\%2oDinner.

Obama, B.H. \& Biden, J. (2008). Blueprint for change: Obama and Biden's plan for America. Retrieved April 16, 2012 from http://www.setav.org/ups/dosya/2846o.pdf.

Obama for America (Ed.) (2007). Connecting and empowering all Americans through technology and innovation. Retrieved April 16, 2012 from http://lessig.org/blog/Fact\%2O Sheet\%2olnnovation\%2oand\%20Technology\%2OPlan\%20FINAL.pdf.

Office of Management and Budget (OMB), Executive Office of the President (2009, 
December 08). Memorandum for the heads of executive departments and agencies. Subject: open government directive. Retrieved January 17, 2012 from http://Www. whitehouse.gov/sites/default/files/omb/assets/memoranda_2010/m10-06.pdf.

White House (2009a, January 21). Memorandum for the heads of executive departments and agencies. Subject: transparency and open government. Retrieved January 17, 2012 from http://www.whitehouse.gov/the_press_office/TransparencyandOpenGovernment.

White House, Office of the Press Secretary (2009b, January 21). Remarks by the President in welcoming senior staff and cabinet secretaries to the White House. Retrieved April 23, 2012 from http://www.whitehouse.gov/the-press-office/remarks-president-welcomingsenior-staff-and-cabinet-secretaries-white-house.

White House (2009c, January 21). Memorandum for the heads of executive departments and agencies. Subject: Freedom of Information Act. Retrieved May 26, 2012 from http:// www.whitehouse.gov/the_press_office/Freedom_of_Information_Act.

White House, Office of the Vice-President (2009d, February 25). Remarks by VicePresident Biden, Director Orszag and Chairman Devaney at the first recovery plan implementation meeting with cabinet secretaries. Retrieved April 23, 2012 from http:// www.whitehouse.gov/the-press-office/remarks-vice-president-biden-director-orzag-andchairman-devaney-first-recovery-plan.

White House, Office of the Press Secretary (2009e, March 11). Remarks by the president on earmark reform. Room 350, Dwight D. Eisenhower Executive Office Building. Retrieved April 29, 2012 from http://www.whitehouse.gov/the-press-office/remarks-presidentearmark-reform.

White House, Office of the Vice-President (2009f, March 12). Opening remarks by the vice-president at the White House Recovery and Reinvestment Act implementation conference. Room 450, Dwight D. Eisenhower Executive Office Building.

Retrieved April 29, 2012 from http://www.whitehouse.gov/the-press-office/remarksvice-president-white-house-recovery-and-reinvestment-act-implementation-con.

White House, Office of the Press Secretary (2009g, March 20). Remarks by the president and the vice-president to representatives of the national conference of state legislatures. Dwight D. Eisenhower Executive Office Building, room 350. Retrieved April 29, 2012 from http://www.whitehouse.gov/the-press-office/remarks-vice-president-andpresident-representatives-national-conference-state-legi.

White House, Office of the Press Secretary (2009h, September 14). Remarks by the president on financial rescue and reform. Speech at Federal Hall, New York City, New York. Retrieved April 29, 2012 from http://www.whitehouse.gov/the-press-office/remarkspresident-financial-rescue-and-reform-federal-hall.

White House, Office of the Vice-President (2009i, October 01). Opening remarks 
by the vice-president at the economic recovery implementation meeting with cabinet members. Dwight D. Eisenhower Executive Building. Retrieved April 29, 2012 from http:// www.whitehouse.gov/the-press-officelopening-remarks-vice-president-economic-recoveryimplementation-meeting-with-cabinet.

White House, Office of the Press Secretary (2009j, November 16). Remarks by President Barack Obama at town hall meeting with future Chinese leaders. Museum of Science and Technology, Shanghai, China. Retrieved June 03, 2012 from http://www.whitehouse.gov/ the-press-office/remarks-president-barack-obama-town-hall-meeting-with-future-chineseleaders.

White House, Office of the Press Secretary (2010a, January 14). Remarks by the president at opening session of the Forum on Modernizing Government. South Court Auditorium, Eisenhower Executive Office Building. Retrieved May 06, 2012 from http://www. whitehouse.gov/the-press-office/remarks-president-opening-session-forum-modernizinggovernment.

White House (2010b, February 03). Remarks by the president at the senate Democratic policy committee issues conference. The Newseum, Washington, DC. Retrieved May 06, 2012 from http://www.whitehouse.gov/the-press-office/remarks-president-senatedemocratic-policy-committee-issues-conference.

White House, Office of the Press Secretary (2010c, April 16). Remarks by the president at a meeting with the President's Economic Recovery Advisory Board. Roosevelt Room. Retrieved May 06, 2012 from http://www.whitehouse.gov/the-press-office/remarkspresident-a-meeting-with-presidents-economic-recovery-board.

White House, Office of the Press Secretary (2010d, July 26). Remarks by the president on the DISCLOSE Act. Rose Garden, the White House. Retrieved May 06, 2012 from http:// www.whitehouse.gov/the-press-office/remarks-president-disclose-act.

White House, Office of the Press Secretary (2010e, September 22). Remarks by the president at DCCC/ DSCC general reception. Roosevelt Hotel, New York City, New York. Retrieved May 24, 2012 from http://www.whitehouse.gov/the-press-office/2010/og/22/ remarks-president-dcccdscc-general-reception.

White House, Office of the Press Secretary (2010f, October 23). Remarks by the president at a rally in Minneapolis, Minnesota. University of Minnesota, Minneapolis, Minnesota. Retrieved May 24, 2012 from http://www.whitehouse.gov/the-press-office/2012/10/23/ remarks-president-a-rally-minneapolis-minnesota.

White House, Office of the Press Secretary (2010g, November 29). Remarks by the president on the federal employee pay freeze. Eisenhower Executive Office Building. Retrieved May 24, 2012 from http://www.whitehouse.gov/the-press-office/2010/11/29/ remarks-president-federal-employee-pay-freeze. 
White House, Office of the Press Secretary (2011a, September 20). Fact sheet: the Open Government Partnership. Retrieved April 29, 2012 from http://www.whitehouse.gov/thepress-office/2011/og/20/fact-sheet-open-government-partnership.

White House, Office of the Press Secretary (2011b, September 20). Opening remarks by President Obama on Open Government Partnership. Waldorf Astoria Hotel, New York City, New York. Retrieved May 25, 2012 from http://www.whitehouse.gov/the-pressoffice/2011/og/20/opening-remarks-president-obama-open-government-partnership.

White House, Office of the Press Secretary (2011c, September 20). Closing remarks by President Obama on Open Government Partnership. Waldorf Astoria Hotel, New York City, New York. Retrieved May 25, 2012 from http://www.whitehouse.gov/the-pressoffice/2011/og/20/closing-remarks-president-obama-open-government-partnership. 